\title{
Gas exchange in gariroba palms grown under subtropical conditions
}

\author{
Valéria A Modolo'; Norma M Erismann²; Maria Luiza S Tucci² \\ ${ }^{1}$ Instituto Agronômico, Centro de Horticultura (IAC), Campinas-SP, Brazil; vamodolo@iac.sp.gov.br; ${ }^{2}$ Instituto Agronômico, Centro de \\ Ecofisiologia e Biofísica (IAC), Campinas-SP, Brazil; normaeri@iac.sp.gov.br; tucci@iac.sp.gov.br
}

\begin{abstract}
Gariroba palm, native to Brazil, produces bitter heart-of-palm, consumed as vegetable in salads, as well as in other Brazilian recipes. This research was carried out in field condition to evaluate diurnal and seasonal variation of gas exchange of gariroba palms cultivated under subtropical conditions, considering their interrelation with some climate elements. Plants were evaluated within two consecutive years, grown under field conditions and irrigated, spaced $2 \times 1 \mathrm{~m}$. Net assimilation of $\mathrm{CO}_{2}\left(\mathrm{P}_{\mathrm{N}}\right)$, stomatal conductance $\left(\mathrm{g}_{\mathrm{s}}\right)$, transpiration (E), leaf temperature $\left(\mathrm{T}_{l}\right)$ within the chamber and the photosynthetic photon flux density (PPFD) were evaluated. Water use efficiency (WUE) was estimated by the ratio: $\mathrm{WUE}=\mathrm{P}_{\mathrm{N}} / \mathrm{E}$. Net $\mathrm{CO}_{2}$ assimilation $\left(\mathrm{P}_{\mathrm{N}}\right)$, showed a plateau in May, observed from 9:30 to $14 \mathrm{~h}$, reaching an average of $5.4 \mu \mathrm{mol} \mathrm{m} \mathrm{m}^{-2} \mathrm{~s}^{-1}$, then declining toward late afternoon. As far as August is concerned, $\mathrm{P}_{\mathrm{N}}$ increased from the early morning until $11 \mathrm{~h}$, reaching the maximum value of $9.0 \mu \mathrm{mol} \mathrm{m}^{-2} \mathrm{~s}^{-1}$. From then on it decreased reaching $6.0 \mu \mathrm{mol} \mathrm{m}^{-2} \mathrm{~s}^{-1}$ at $14 \mathrm{~h}$. Gariroba palms cultivated and even under lower autumn and winter temperatures presented gas exchange characteristics consistent to climatic elements.
\end{abstract}

Keywords: Syagrus oleracea, photosynthesis, bitter heart-of-palm.

\begin{abstract}
RESUMO
Trocas gasosas em palmeira gariroba cultivada sob condições subtropicais

Nativa do Brasil, a garirobeira produz palmito amargo, consumido como hortaliça em saladas, bem como em outras receitas da culinária brasileira. Este trabalho foi realizado em condição de campo para avaliar as variações diurnas das trocas gasosas de garirobeiras, considerando sua inter-relação com alguns elementos climáticos. Foram realizadas avaliações em garirobeiras cultivadas no espaçamento $2 \mathrm{x} 1$ $\mathrm{m}$, conduzidas sob irrigação, durante dois anos consecutivos. Foram avaliadas a assimilação líquida de $\mathrm{CO}_{2}\left(\mathrm{P}_{\mathrm{N}}\right)$, condutância estomática $\left(\mathrm{g}_{s}\right)$, transpiração $(\mathrm{E})$, temperatura foliar $\left(\mathrm{T}_{\mathrm{f}}\right)$ dentro da câmara e densidade de fluxo de fótons fotossinteticamente ativos (DFFF). A eficiência do uso da água (EUA) foi estimada pela razão: EUA $=\mathrm{P}_{\mathrm{N}} / \mathrm{E}$. A assimilação líquida de $\mathrm{CO}_{2}\left(\mathrm{P}_{\mathrm{N}}\right)$, mostrou um platô em maio, observado entre 9 e $14 \mathrm{~h}$, atingindo média de $5,4 \mu \mathrm{mol} \mathrm{m} \mathrm{m}^{-2} \mathrm{~s}^{-1}$, em seguida declinando no fim da tarde. Em agosto, $\mathrm{P}_{\mathrm{N}}$ aumentou a partir do início da manhã até as $11 \mathrm{~h}$, quando atingiu o máximo de 9,0 $\mu \mathrm{mol} \mathrm{m} \mathrm{m}^{-2} \mathrm{~s}^{-1}$. A partir de então, decresceu, atingindo $6,0 \mu \mathrm{mol} \mathrm{m} \mathrm{m}^{-2} \mathrm{~s}^{-1}$ às $14 \mathrm{~h}$. Mesmo sob temperaturas mais baixas de outono e inverno as garirobeiras cultivadas apresentaram trocas gasosas compatíveis com os elementos do clima.
\end{abstract}

Palavras-chave: Syagrus oleracea, fotossíntese, palmito amargo.

\section{Received on February 16, 2017; accepted on February 9, 2018}

$\mathbf{H}^{-\infty}$ eart-of-palm, a product from the upper part of the stem of some palms was already consumed by several native people in Brazil as well as other countries of South and Central America, since ancient times. The abundance of this vegetal material as well as its acceptation by consumers made heartof-palm to be considered a gourmet vegetable, allowing establishment of rentable market based on exploitation of this product (Modolo et al., 2013).

Many palm species of the Brazilian flora are appreciated and the most important market is represented by those of sweet type such as juçara palm (Euterpe edulis), açaí (Euterpe oleracea) and peach palm (Bactris gasipaes) (Modolo et al., 2012).
Gariroba palm (Syagrus oleracea), also known as guariroba, gueroba, gueiroba, guerova, differs from other heart-of-palm producing palms by the characteristic flavor of its heart-of-palm, presenting high content of phenols that gives a bitter and astringent taste, highly appreciated in the culinary of many regions. This characteristic results probably from the high tannin content (almost three times higher than the juçara palm) as well as some amino acids such as phenylalanine, tyrosine and proline (Shimokomaki et al., 1975). Besides the bitter taste, heart-of-palm presents a harder consistency once its major part is of caulinar type. The edible portion weighs from 0.5 to 3.0 $\mathrm{kg}$ in average.
Gariroba palm is native to semideciduous forests as well as to the Brazilian "cerrado" occurring naturally in a wide range, including Bahia, Minas Gerais, São Paulo, Mato Grosso, Mato Grosso do Sul, Goiás and Tocantins (Lorenzi et al., 2010). Due to its geographic origin, this species is acclimated to high sun radiation and low rain precipitation from 800 to $1200 \mathrm{~mm} /$ year, withstanding soil water deficits throughout the winter months. Nevertheless, for commercial gariroba palm production, planting density is high, that is 10.000 to 22.000 plants ha $^{-1}$ (Modolo, 2014) and thus restriction factors to plant growth (fertilization and water deficit) should be observed. The lack of a cultivar makes plant growth 
and consequently harvesting uneven, even under proper cultivation conditions (plants are maintained on the same area for 3 to 4 years). The knowledge of gariroba palm gas exchange under subtropical conditions will contribute to comprehension of its photosynthetic pattern under irrigation.

Palms show maximum values of $\mathrm{CO}_{2}$ assimilation $\left(\mathrm{P}_{\mathrm{N}}\right)$ under $20 \mu \mathrm{mol} \mathrm{m} \mathrm{m}^{-2} \mathrm{~s}^{-1}$ (Jayasekara \& Jayasekara, 1995). On the other hand, Larcher (2000), suggested for $\mathrm{C} 3$ trees, maximum $\mathrm{P}_{\mathrm{N}}$ between 10 and $15 \mu \mathrm{mol} \mathrm{m} \mathrm{m}^{-2} \mathrm{~s}^{-1}$. Differently to what has been observed for palms of more economical importance like coconut (Gomes \& Prado, 2007; Gomes et al., 2008; Passos et al., 2009), oil palm (Dufrêne \& Saugier, 1993; Suresh et $a l ., 2012)$ and lately the heart-of-palm producer palms (Tucci et al., 2007, 2010; Lavinsky et al., 2014; Pereira et al., 2014), no references to gariroba palms gas exchange were found.

Nevertheless, regarding other species of genus Syagrus, a study was carried out on the species $S$. coronata, under greenhouse conditions and water deficit imposed by water withdraw, and a tolerance of photosynthetic apparatus to drought was observed (Medeiros et al., 2015). In dry season of the Brazilian northeast semi-arid, S. coronata, presented low sensibility to low water availability and high water use efficiency (Oliveira et al., 2016). Regarding anatomic characteristics of leaves, the species of genus Syagrus present a thick cuticle that can be considered a protection against desiccation, once these species thrive in regions prone to soil water deficits (Leite \& Scatena, 2001; Oliveira et al., 2016).

It is known that gas exchange variation both diurnal and seasonal are influenced by climate elements characteristic of the region, mainly light, air temperature and air relative humidity, besides soil water availability (Koslowski \& Pallardi, 1997).

This research was carried out to evaluate diurnal and seasonal variation of gas exchange of gariroba palms cultivated under subtropical conditions, considering their interrelation with some climate elements.

\section{MATERIAL AND METHODS}

The experiment was carried out at Campinas Experimental Center, Instituto Agronômico (IAC), in Campinas, São Paulo State, Brazil (22 $54^{\circ}$ 'S; $47^{\circ} 05^{\prime} \mathrm{O}$, $674 \mathrm{~m}$ altitude). According to Köppen classification, the climate is Cwa with a warm and rainy season from October to March, medium air temperature from 22 to $24^{\circ} \mathrm{C}$ and $1057 \mathrm{~mm}$ precipitation; a dry season from April to September, with medium air temperature varying from 18 to $22^{\circ} \mathrm{C}, 325 \mathrm{~mm}$ precipitation, according to Ortolani et al. (1995).

Young gariroba palm plants raised from seeds of open pollinated matrices were transplanted to field conditions, spaced $2 \times 1 \mathrm{~m}$. Soil analysis at the beginning of the experiment presented the following chemical characteristics: $\mathrm{pH}\left(\mathrm{CaCl}_{2}\right)=6.0$; organic matter $(\mathrm{g}$ $\left.\mathrm{dm}^{-3}\right)=29.0$; C.T.C $\left(\right.$ mmolc $\left.\mathrm{dm}^{-3}\right)=$ $100.4 ; \mathrm{V} \%=78 \%$; $\mathrm{P}\left(\mathrm{mg} \mathrm{dm}^{-3}\right)=40.0$; $\mathrm{K}\left(\mathrm{mmolc} \mathrm{dm}{ }^{-3}\right)=2.9 ; \mathrm{Ca}\left(\mathrm{mmolc} \mathrm{dm}^{-3}\right)$ $=53.0 ; \mathrm{Mg}\left(\mathrm{mmolc} \mathrm{dm}^{-3}\right)=22.0 ; \mathrm{Fe}$ $\left(\mathrm{mg} \mathrm{dm}^{-3}\right)=14.0 ; \mathrm{Mn}\left(\mathrm{mg} \mathrm{dm}^{-3}\right)=5.9$; $\mathrm{Cu}\left(\mathrm{mg} \mathrm{dm}^{-3}\right)=4.1 ; \mathrm{Zn}\left(\mathrm{mg} \mathrm{dm}^{-3}\right)=$ 1.2; $\mathrm{B}\left(\mathrm{mg} \mathrm{dm}^{-3}\right)=0.25 ; \mathrm{H}+\mathrm{Al}($ mmolc $\left.\mathrm{dm}^{-3}\right)=22.0$; S.B. $\left(\mathrm{mmolc} \mathrm{dm}^{-3}\right)=77.9$. Two months before transplantation the area was plowed and, according to soil analysis and recommendation (Bovi \& Bortoletto, 1998), $500 \mathrm{~kg} \mathrm{ha}^{-1}$ of dolomitic limestone were incorporated. After, grooves were opened for the young plants transplantation. No chemical fertilization was applied at planting. According to soil analysis $120 \mathrm{~g}$ of N, $12 \mathrm{~g}$ of $\mathrm{K}_{2} \mathrm{O}$ and $6 \mathrm{~g}$ of $\mathrm{P}_{2} \mathrm{O}_{5}$ were applied per plant, four doses per year, starting seven month after planting. Plants were irrigated through microaspersion, one emissor for each 2 plants and defined according to culture evapotranspiration $\left(\mathrm{ET}_{\mathrm{C}}\right)$, estimated using the reference evapotranspiration (ETo) by PenmanMonteith method (Allen et al., 1998), calculated based on meteorological data of the local climate station. According to Delgado-Rojas et al. (2012), the transpiration of an irrigated area of peach palm represents $92 \%$ of the ETo on average; therefore considering decrease of the irrigation efficiency due to direct evapotranspiration, the crop coefficient $(\mathrm{Kc})$ for peach palm is considered to be 1, that is ETc $=$ ETo. On the other hand, despite the fact that gariroba palm does not emit off-shoots like peach palm, it has same growth characteristic and approximately same foliar area. Therefore the use of same parameter of ETc estimative was chosen to irrigate the experimental area. In the first year, six month-old gariroba palms still presenting biphid leaves were evaluated. Gas exchange evaluations were carried out under field conditions, in May 2012. In August 2013, gariroba palms of the same area now 21 monthold, presenting pinnate leaves, were evaluated.

Experiment was arranged in a completely random design and data were subjected to analyses of variance considering both evaluation months (May and August) and time of day (five times) as source of variation. Net $\mathrm{CO}_{2}$ assimilation $\left(\mathrm{P}_{\mathrm{N}}\right)$, stomatal conductance $\left(\mathrm{g}_{\mathrm{s}}\right)$, transpiration (E), leaf temperature $\left(\mathrm{T}_{l}\right)$ inside chamber and photosynthetic photon flux density (PPFD) were evaluated. Evaluations were performed with a portable infrared gas analyzer (LCA-4, ADC BioScientific Ltd., Great Amwell, U.K.). Water use efficiency (WUE) was estimated by the ratio $\mathrm{WUE}=\mathrm{P}_{\mathrm{N}} / \mathrm{E}$. Measurements were performed on the medium portion of the youngest completely expanded leaf (leaf +1 ), according to Tomlinson criteria (Tomlinson, 1990) and throughout the experiment, leaves of the same ontogenetic state were evaluated, for both dry and wet seasons in sunny days from 8 to $17 \mathrm{~h}$. Air temperatures and relative humidity $(\mathrm{RH})$ were monitored by a meteorological station at $300 \mathrm{~m}$ from the experimental area. Average diurnal data were calculated from 3 to 6 replications. When significance was observed mean values were submitted to Student-Newman-Keuls multiple range test $(p \leq 0.05)$. Graphs were performed according to Origin 6.0 (OriginLab Corp., Northampton, USA) program.

\section{RESULTS AND DISCUSSION}

Under subtropical conditions it is important to consider that once plants had been irrigated, other climate 


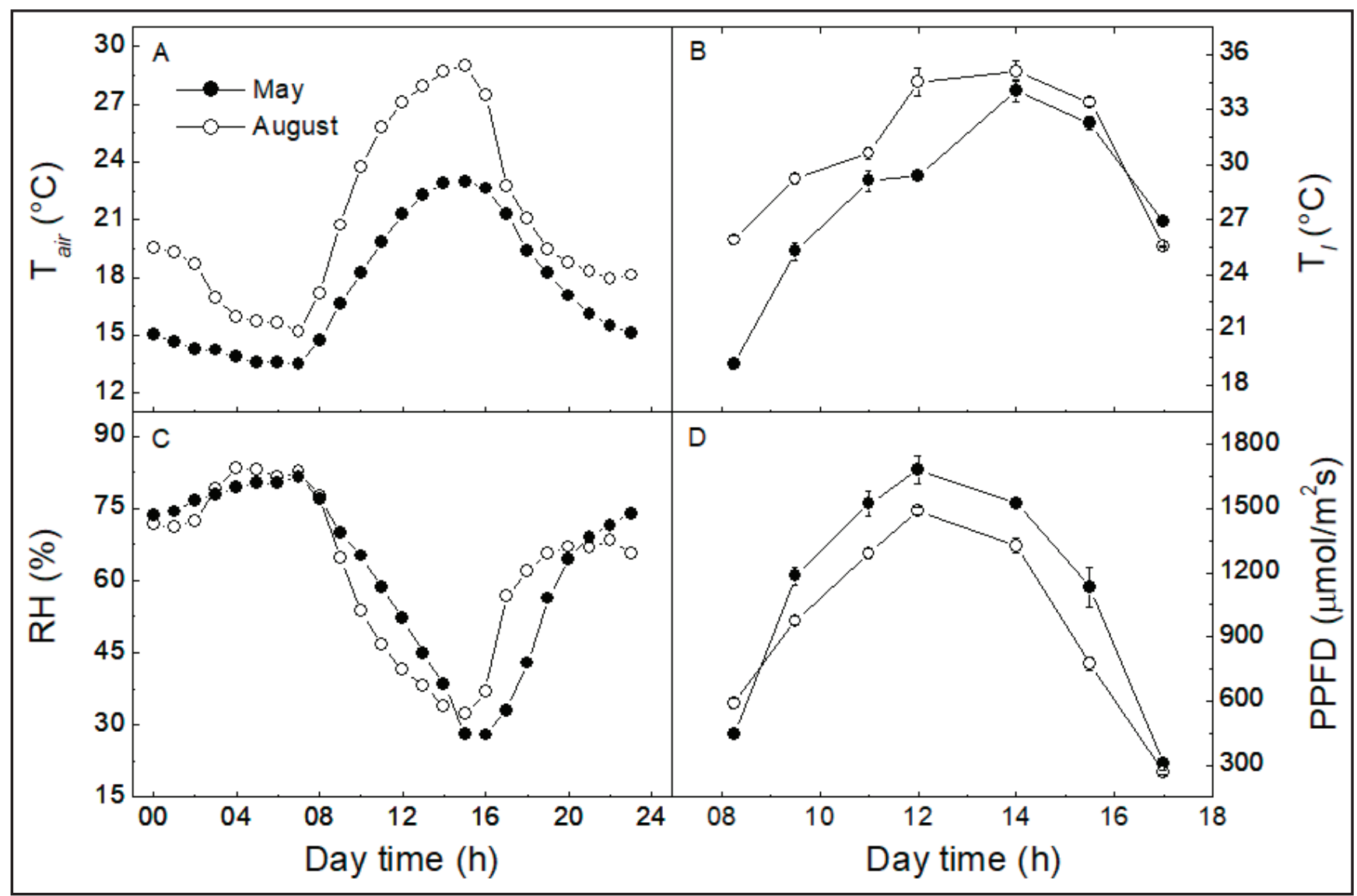

Figure 1. Diurnal courses of average air temperature $\left(\mathrm{T}_{\text {air }}\right)$ and relative air humidity $(\mathrm{RH})(\mathrm{A}, \mathrm{C})$, provided by a meteorological station, and leaf temperature $\left(\mathrm{T}_{l}\right)$ and photosynthetic photon flux density (PPFD) (B, D), registered inside the gas analyzer chamber on May, $2012(\bullet)$ and on August, 2013 (०). Note that the scales on the x-axes of the right frames are different from those on the left. Campinas, IAC, $2012 / 2013$.

elements other than the soil water status can have imposed some effect on gas exchange.

Concerning air temperature in May, minimum $\left(14^{\circ} \mathrm{C}\right)$ and maximum $\left(23^{\circ} \mathrm{C}\right)$ values were observed at 7 and at 15 $\mathrm{h}$, respectively. Whereas $\mathrm{RH}$ was minimum from 15 to $16 \mathrm{~h}$, reaching $28 \%$, leaf temperature varied from 19 to $34^{\circ} \mathrm{C}$, at 8 and $14 \mathrm{~h}$ respectively (Figure 1A and 1B). In August 2013 air temperatures were higher, with minimum $\left(15^{\circ} \mathrm{C}\right)$ and maximum $\left(29^{\circ} \mathrm{C}\right)$ values observed at 7 and 15 $\mathrm{h}$, respectively with leaf temperature varying from 26 to $35^{\circ} \mathrm{C}$, from 8:30 to 13:30 h, respectively, whereas RH was minimum at $15 \mathrm{~h}$ reaching $32 \%$ (Figure $1 \mathrm{C}$ and 1D). Measurements in May 2012 were performed under autumn conditions, with milder air temperatures than the occurring on following year (August 2013), end of winter, with plants prepared to another growth cycle.

Regarding gas exchange, variance analyses of both evaluations showed significant difference $(\mathrm{p} \leq 0.05)$ among days and hours for the following variables $\mathrm{P}_{\mathrm{N}}, \mathrm{g}_{s}, \mathrm{E}, \mathrm{T}_{l}$ and PPFD. On the other hand for WUE, differences were observed $(\mathrm{p} \leq 0.05)$ only among hours.

$\mathrm{P}_{\mathrm{N}}, \mathrm{g}_{s}, \mathrm{E}, \mathrm{T}_{l}$ were higher at second year. Average values of $\mathrm{P}_{\mathrm{N}}$, including all measurement times were 4.0 and $6.5 \mu \mathrm{mol} \mathrm{m}{ }^{-2} \mathrm{~s}^{-1}$ for the first and second years, respectively. Concerning $\mathrm{g}_{s}$, medium values were $0.172 \mathrm{~mol} \mathrm{~m}^{-2}$ $\mathrm{s}^{-1}$ at first year and higher at second year reaching $0.238 \mathrm{~mol} \mathrm{~m}^{-2} \mathrm{~s}^{-1}$. E corresponded to 1.59 and $2.66 \mathrm{mmol} \mathrm{m}^{-2}$ $\mathrm{s}^{-1}$ at first and second years, respectively, whereas average value of $\mathrm{T}_{l}$ presented the same tendency, lower at first year $\left(27.6^{\circ} \mathrm{C}\right)$ and higher at second $\left(30.6^{\circ} \mathrm{C}\right)$. Like it was observed for peach palm (Tucci et al., 2010), although other climate elements were favorable, $\mathrm{P}_{\mathrm{N}}$ was lower because of the lower temperature at the night previous to measurements.

It is known that climate elements mainly PPFD, temperature and air RH influence directly gas exchange of all plant species and its impact is of high importance to physiology of production, once productivity depends highly on the $\mathrm{P}_{\mathrm{N}}$ throughout the crop cycle (Taiz \& Zeiger, 2009).

Like all palms (Tucci et al., 2010; Prado et al. 2001; Passos et al., 2009), gariroba palm presented diurnal variation of gas exchange with a performance consistent with that of photosynthetic metabolism of $\mathrm{C} 3$ plants (Larcher, 2000), both in May and in August (Figure 2 and 3).

Daily courses of $\mathrm{P}_{\mathrm{N}}, \mathrm{g}_{s}$ E, WUE, showed variations according to climate conditions observed throughout evaluations in May (Figure 2) and August (Figure 2). In May, 2012, $\mathrm{P}_{\mathrm{N}}$ increased in early morning (Figure 2A) following the increase of PPFD (Figure 1B), remaining constant until $14 \mathrm{~h}$. The maximum medium value of $\mathrm{P}_{\mathrm{N}}$ observed at the plateau from 9 to 14 


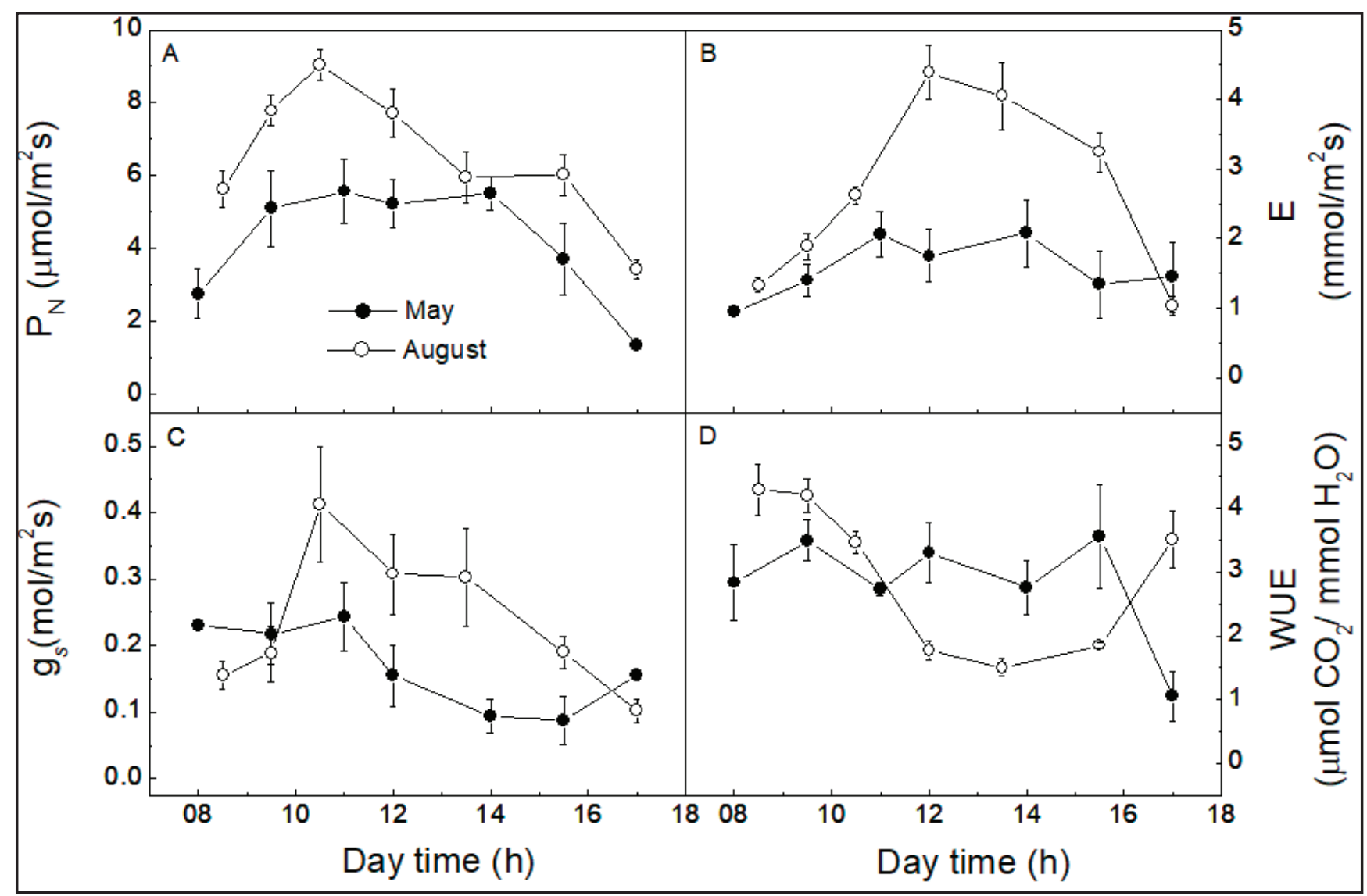

Figure 2. Diurnal courses of net $\mathrm{CO}_{2}$ assimilation - $\mathrm{P}_{\mathrm{N}}(\mathrm{A})$, transpiration - E (B), stomatal conductance - $\mathrm{g}_{\mathrm{s}}(\mathrm{C})$ and water use efficiency WUE (D), in gariroba palms, on May, $2012(\bullet)$ and on August, $2013(\circ)$. Each symbol represents the mean value ( \pm standard error) of three to six replications. Campinas, IAC, 2013.

$\mathrm{h}$ was $5.4 \mu \mathrm{mol} \mathrm{m} \mathrm{m}^{-2} \mathrm{~s}^{-1}$. A depression was not noted neither on the $\mathrm{P}_{\mathrm{N}}$ curve nor on the E curve at $14 \mathrm{~h}$, although $\mathrm{g}$ value was lower.

Values of $g$ remained around 0.23 mol m${ }^{-2} \mathrm{~s}^{-1}$ from 8 to $11 \mathrm{~h}$, declining with decrease of RH in afternoon, although E remained constant, around $2.0 \mathrm{mmol}$ $\mathrm{m}^{-2} \mathrm{~s}^{-1}$ until $14 \mathrm{~h}$. From 14 to $16 \mathrm{~h} \mathrm{P}_{\mathrm{N}}$ decreased probably due to decrease of $g$ and to the low $\mathrm{RH}$ that reached $28 \%$, despite the fact that PPFD was over $1000 \mu \mathrm{mol} \mathrm{m} \mathrm{m}^{-2} \mathrm{~s}^{-1}$, what for a C3 plant like gariroba palm is over the photosynthesis saturation by PPFD (Larcher 2000). WUE (Figure 2D) remained high from early morning to $16 \mathrm{~h} . \mathrm{P}_{\mathrm{N}}$ decrease at $16 \mathrm{~h}$ followed the low PPFD of late afternoon (Figure 1B).

Regarding the daily courses observed in August (Figure 2), $\mathrm{P}_{\mathrm{N}}$ increased from early morning to $11 \mathrm{~h}$, when it reached the maximum value of $9.0 \mu \mathrm{mol} \mathrm{m} \mathrm{m}^{-2} \mathrm{~s}^{-1}$. From then on $\mathrm{P}_{\mathrm{N}}$ decreased $33 \%$ until 14 $\mathrm{h}(\mathrm{p} \leq 0.05)$, reaching $6.0 \mu \mathrm{mol} \mathrm{m}^{-2} \mathrm{~s}^{-1}$ at 14 $\mathrm{h}$ still under PPFD over $1200 \mu \mathrm{mol} \mathrm{m} \mathrm{m}^{-2} \mathrm{~s}^{-1}$. From 14 to $16 \mathrm{~h} \mathrm{P}_{\mathrm{N}}$ values remained constant, dropping with PPFD decrease (Figure 1D).

Diurnal variation of $g_{s}$ followed the same $\mathrm{P}_{\mathrm{N}}$ pattern, presenting maximum value of $0.412 \mathrm{~mol} \mathrm{~m}^{-2} \mathrm{~s}^{-1}$, under maximum $\mathrm{P}_{\mathrm{N}}$ (Figure 2C). On the other hand, E was maximum reaching $4.4 \mathrm{mmol} \mathrm{m}^{-2} \mathrm{~s}^{-1}$ around noon, when $\mathrm{T}_{1}$ reached the maximum value of $35^{\circ} \mathrm{C}$. From this point on, $g$ and $\mathrm{P}_{\mathrm{N}}$ decreased (Figure 1 and 3). After $12 \mathrm{~h}$, higher values of air temperature and $\mathrm{T}_{l}$ were observed, concomitantly to lower values of RH (Figure 1C), what may have contributed for the decrease of WUE from 12 to $16 \mathrm{~h}$, when it reached values under $2.0 \mu \mathrm{mol} \mathrm{CO} / \mathrm{mmol} \mathrm{H}_{2} 0$. From then on it recovered the status of the early morning, over $3 \mu \mathrm{mol} \mathrm{CO} / \mathrm{mmol}$ $\mathrm{H}_{2} \mathrm{O}$ (Figure 2D).

It is important to remember that gariroba palms were under irrigation throughout the experiment and therefore variations of $g_{s}$ and $P_{N}$ have notbeen due to soil water deficit, but to atmospheric conditions of the evaluation days.

Results can be considered consistent with the environmental conditions observed when measurements were performed. Maximum $\mathrm{P}_{\mathrm{N}}$ value of 9.0 $\mu \mathrm{mol} \mathrm{m} \mathrm{m}^{-2} \mathrm{~s}^{-1}$ in August can be compared to that of $10 \mu \mathrm{mol} \mathrm{m}^{-2} \mathrm{~s}^{-1}$ observed for $S$. coronata under field conditions of the Pernanbuco State semi-arid region in the rainy season (Oliveira et al., 2016). In irrigated peach palms under subtropical conditions of São Paulo State, Brazil, $\mathrm{P}_{\mathrm{N}}$ maximum reached $15 \mu \mathrm{mol} \mathrm{m} \mathrm{m}^{-2} \mathrm{~s}^{-1}$ in February (Tucci et al., 2010). In other palms of economic importance, like dwarf coconut, $\mathrm{P}_{\mathrm{N}}$ reached values of 14$17 \mu \mathrm{mol} \mathrm{m}{ }^{-2} \mathrm{~s}^{-1}$ (Gomes \& Prado, 2007; Gomes et al. 2008; Passos et al. 2009).

Therefore, it can be considered that maximum values of $P_{N}$ of 5.4 and 9.0 $\mu \mathrm{mol} \mathrm{m} \mathrm{m}^{-2} \mathrm{~s}^{-1}$ observed for gariroba palms in May and August respectively, could 
not represent the maximum limit for $\mathrm{P}_{\mathrm{N}}$ of the species. In other seasons, under favorable conditions, such as hot and humid summers, gariroba palm may present maximum values of $\mathrm{P}_{\mathrm{N}}$ higher than the mentioned in present study. Therefore it is important to consider that gas exchange measurements were performed in May and August when air temperatures at night and pre-dawn reached minimum values of $14-15^{\circ} \mathrm{C}$ (Figure 1A and 1C). This fact could have contributed to the decline of gariroba palm $\mathrm{P}_{\mathrm{N}}$ mainly in May, when air temperature remained under $15^{\circ} \mathrm{C}$ during 7 hours (Figure 1A).

It is worth observing that evaluations were performed in May and August, autumn and winter, respectively. As a matter of fact, according to what has been related for peach palm (Tucci et al., 2010), low night temperatures lowered the photosynthetic response. The same effect was observed in other species like mango (Allen et al., 2000) and citrus (Ribeiro et al., 2009 a,b), what was considered by Allen et al. (2000), as a consequence of a stomatal limitation of $\mathrm{P}_{\mathrm{N}}$ due to an increase of sensitivity of guard cells to intercellular $\mathrm{CO}_{2}$.

In August, but not in May (Figure 2 ), variation of diurnal course of gas exchange followed the model described by Koslowski \& Pallardi (1997) for tropical plants, that is, $P_{N}$ increased sharply at the beginning of morning, paralleling PPFD, reaching the maximum value at mid morning. On the other hand, in May probably due to night (and diurnal) temperatures lower than in August (Figure 1A and 1C), stomata were maintained more closed throughout the day course, with lower values of $\mathrm{P}_{\mathrm{N}}$ throughout the day, without showing the characteristic peak in morning.

Results showed that under subtropical conditions, gariroba palms cultivated under irrigation, even under the lower temperatures of autumn and winter, showed gas exchange consistent with the climate elements. Nevertheless, considering the climate seasonality and its direct effects on heart-of-palms production, other studies under other season conditions would be performed.

\section{REFERENCES}

ALLEN, KJ; RATNER, K; GILLER, YE; GUSSAKOVSKY, EE; SHAHAK, Y; ORT, DR. 2000. An overnight chill induces a delayed inhibition of photosynthesis at midday in mango (Mangifera indica L.). Journal of Exp. Botany 51: 1893-1902.

BOVI, MLA; BORTOLETTO, N. 1998. Palmito - gariroba. In: FAHL, JI; CAMARGO, MBP; PIZZINATTO, MA; BETTI, JA; MELO, AMT; MARIA, IC; FURLANI, AMC (eds). Boletim 200: Instruções Agrícolas para as principais culturas econômicas. Campinas: Instituto Agronômico. 6. ed. rev. atual. p. 258-259.

DELGADO-ROJAS, JS; FOLEGATTI, MV; MODOLO, VA; TUCCI, MLS. 2012. Potential transpiration of peach palms under Southeastern Brazil conditions. Acta Horticulturae 936: 95-102.

DUFRÊNE, E; SAUGIER, B. 1993. Gas exchange of oil palm in relation to light, vapour pressure deficit, temperature and leaf age. Funct. Ecol. 7: $97-104$

GOMES, FP; OLIVA, MA; MIELKE, MS; ALMEIDA, AAF; LEITE, HG; AQUINO, LA. 2008. Photosynthetic limitations in leaves of young Brazilian green dwarf coconut (Cocos nucifera L. 'nana') palm under well-watered conditions or recovering from drought stress. Environ. Exp. Bot. 62: 195-204.

GOMES, FP; PRADO, CHBA. 2007. Ecophysiology of coconut palm under water stress. Brazilian Journal of Plant Physiology 19: 377-391.

JAYASEKARA, C; JAYASEKARA, KS. 1995. Photosynthetic characteristics of tropical tree species with special reference to palms. Ener. Conver. Manag. 36: 919-922.

KOSLOWSKI, T; PALLARDY, SG. 1997. Photosynthesis. In: KOSLOWSKI, T; PALLARDY, SG. Physiology of woody plants. $2^{\text {nd }}$ Ed., New York: Academic Press, Inc. p.87-132.

LARCHER, W. 2000. A planta sob estresse. In: LARCHER W. (ed). Ecofisiologia vegetal. São Carlos: RiMa. p.341-378.

LAVINSKY, AO; GOMES, FP; MIELKE, MS; FRANÇA, S. 2014. Photosynthetic acclimation in shade-developed leaves of Euterpe edulis Mart (Arecaceae) after longterm exposure to high light. Photosynthetica 52: 351-357. http://dx.doi.org/10.1007/ s11099-014-0038-5.

LEITE, KRB; SCATENA, VL. 2001. Anatomy of the leaf segments of the species of Syagrus Mart. (Arecaceae) of the Chapada Diamantina, Bahia, Brazil. Sitientibus série Ciências Biológicas 1: 3-14.

LORENZI, H; NOBLICK, L; KAHN, EP. 2010. Flora brasileira: Arecaceae (Palmeiras). Nova Odessa: Instituto Plantarum. 368p.

MEDEIROS, MJ; OLIVEIRA, DS; OLIVEIRA, MT; WILLADINO, L; HOULLOU, L; SANTOS, MG. 2015. Ecophysiological, anatomical and biochemical aspects of in vitro culture of zygotic Syagrus coronata embryos and of young plants under drought stress. Trees
29: 1219-1233. http://dx.doi.org/10.1007/ s00468-015-1202-7.

MODOLO, VA; ANEFALOS, LC; TUCCI, MLS. 2012. Situação atual e perspectivas do cultivo de palmeiras para produção de palmito de alta qualidade. In: CONGRESSO BRASILEIRO DE OLERICULTURA, 52. Horticultura Brasileira 30 : S8473-S8481. http://www.abhorticultura. com.br/eventosx $2 /$ eventosx/AdmTrabalhos. aspx ?idevento $=6 \&$ tipo $=$ PALESTRAS

MODOLO, VA; ANEFALOS, LC; TUCCI, MLS. 2013. Commercial growing of peach palms for heart-of-palm production. Acta Horticulturae 1003: 73-80.

MODOLO, VA. 2014. Palmito pupunha. In: AGUIAR, ATE; GONÇALVES, C; PATERNIANI, MEGZ; TUCCI, ML; CASTRO, CEF (orgs). Instruções agrícolas para as principais culturas econômicas Boletim 200 IAC. 7 ed. Campinas-SP: IAC, p.329-333.

OLIVEIRA, D; MEDEIROS, M; PEREIRA, S; OLIVEIRA, M; FROSI, G; ARRUDA, E; SANTOS, M. 2016. Ecophysiological leaf traits of native and exotic palm tree species under semi-arid conditions. Bragantia 75: 128-134. http://dx.doi.org/10.1590/16784499.364.

ORTOLANI, AA; CAMARGO, MBP; PEDRO, JUNIOR, MJ. 1995. Normais climatológicas dos postos meteorológicos do Instituto Agronômico: 1. Centro Experimental de Campinas. Boetim Técnico do Instituto Agronômico. 13p.

PASSOS, EEM; PRADO, CHBA; ARAGÃO, WM. 2009. The influence of vapour pressure deficit on leaf water relations of Cocos nucifera in northeast Brazil. Expl. Agri. 45: 93-106.

PEREIRA, TS; LOBATO, AKS; ALVES, GAR; FERREIRA, RN; SILVA, ON; MARTINS FILHO, AP; PEREIRA, ES; SAMPAIO, LS. 2014. Tolerance to waterlogging in young Euterpe oleracea plants. Photosynthetica 52: 186-192. http://dx.doi.org/10.1007/ s11099014-0021-1.

PRADO, CHBA; PASSOS, EEM; MORAES, JAPV. 2001. Photosynthesis and water relations of six tall genotypes of Cocos nucifera in wet and dry seasons. South African Journal of Botany 67:169-176.

RIBEIRO, RV; MACHADO, EC; SANTOS, MG; OLIVEIRA, RF. 2009a. Photosynthesis and water relations of well-watered orange plants as affected by winter and summer conditions. Photosynthetica 47: 215-222.

RIBEIRO, RV; MACHADO, EC; SANTOS, MG; OLIVEIRA, RF. 2009b. Seasonal and diurnal changes in photosynthetic limitation of young sweet orange trees. Environ. Exp. Bot. 66: 203-211.

SHIMOKOMAKI, M; ABDALA, C.; FRANCA, JF; DRAETTA, IS; FIGUEIREDO, IB; ANGELUCCI, E. 1975. Estudo comparativo entre palmitos de sabor doce (juçara-Euterpe edulis Mart. e açaí Euterpe oleracea Mart.) e de sabor amargo (guariroba-Syagrus oleracea Becc.). In: Composição química, peptídeos e aminoácidos livres. Coletânea do Instituto de 
Tecnologia de Alimentos 6: 69-80.

SURESH, K; NAGAMANI, C; KANTHA, DL; KUMAR, MK. 2012. Changes in photosynthetic activity in five common hybrids of oil palm (Elaeis guineensis Jacq.) seedlings under water deficit. Photosynthetica 50: 549-556. http://dx.doi.org/10.1007/s11099-
012-0062-2.

TAIZ, L; ZEIGER, E. 2009. Fisiologia Vegetal. 4ed. trad. Porto Alegre: Artmed. 848p.

TOMLINSON, PB. 1990. The structural biology of palms. Oxford: Clarendon Press. 463p.

TUCCI, MLS; BOVI, MLA; MACHADO, EC; SPIERING, SH. 2007. Seasonal variation in growth of peach palms cultivated in containers under subtropical conditions. Scientia Agricola 64: 138-146.

TUCCI, MLS; ERISMANN, NM; MACHADO, EC; RIBEIRO, RV. 2010. Diurnal and seasonal variation in photosynthesis of peach palms grown under subtropical conditions. Photosynthetica 48: 421-429. 